Prepared in cooperation with the University of British Columbia, Biodiversity Research Centre and Beaty Biodiversity Museum and the University of Montana, Division of Biological Sciences

\title{
Bull Trout in the Boundary System-Managing Connectivity and the Feasibility of a Reintroduction in the Lower Pend Oreille River, Northeastern Washington
}

Open-File Report 2014-1229 



\section{Bull Trout in the Boundary System-Managing Connectivity and the Feasibility of a Reintroduction in the Lower Pend Oreille River, Northeastern Washington}

By Jason B. Dunham, Eric B. Taylor, and Fred W. Allendorf

Prepared in cooperation with the University of British Columbia, Biodiversity Research Centre and Beaty

Biodiversity Museum and the University of Montana, Division of Biological Sciences

Open-File Report 2014-1229

U.S. Department of the Interior

U.S. Geological Survey 


\section{U.S. Department of the Interior \\ SALLY JEWELL, Secretary}

\section{U.S. Geological Survey \\ Suzette M. Kimball, Acting Director}

U.S. Geological Survey, Reston, Virginia: 2014

For more information on the USGS-the Federal source for science about the Earth, its natural and living resources, natural hazards, and the environment-visit http://www.usgs.gov or call 1-888-ASK-USGS

For an overview of USGS information products, including maps, imagery, and publications, visit http://www.usgs.gov/pubprod

To order this and other USGS information products, visit http://store.usgs.gov

Suggested citation:

Dunham, J.B., Taylor, E.B., and Allendorf, F.W., 2014, Bull trout in the Boundary System-Managing connectivity and the feasibility of a reintroduction in the lower Pend Oreille River, northeastern Washington: U.S. Geological Survey Open-File Report 2014-1229, 28 p., http://dx.doi.org/10.3133/ofr20141229.

ISSN 2331-1258 (online)

Any use of trade, firm, or product names is for descriptive purposes only and does not imply endorsement by the U.S. Government.

Although this information product, for the most part, is in the public domain, it also may contain copyrighted materials as noted in the text. Permission to reproduce copyrighted items must be secured from the copyright owner. 


\section{Contents}

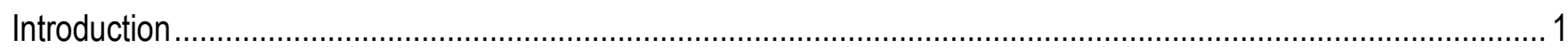

The Boundary System —Synopsis of Relevant Details ............................................................................. 3

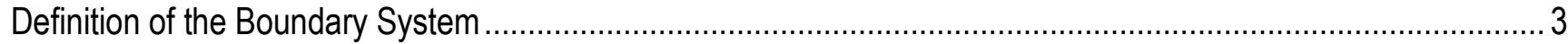

Relicensing of Boundary Dam.........................................................................................................

Passage of Bull Trout over Boundary Dam............................................................................................ 4

Historical Context of Connectivity between Salmo River and Boundary System Bull Trout .................................. 4

Natural Historical Connectivity ……………………………..........................................................

Contemporary Ecological Connectivity.............................................................................................

Feasibility of Establishing Bull Trout in the Boundary System ........................................................................ 7

Historical Occupancy and Likelihood of Natural Recolonization..................................................................... 8

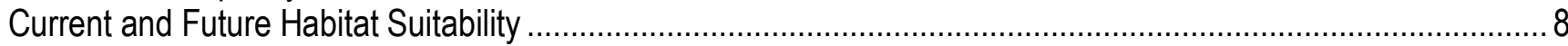

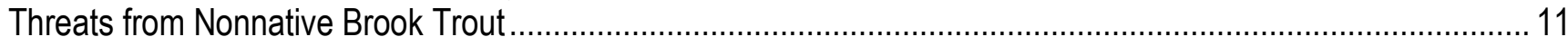

Suitability of Available Donor Populations ........................................................................................ 11

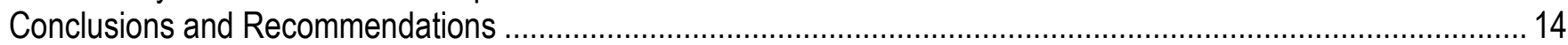

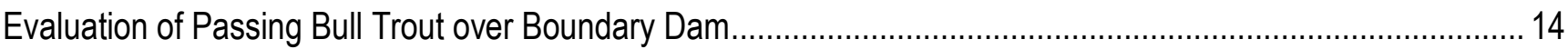

Establishing a Self-Sustaining Population in the Boundary System .............................................................. 14

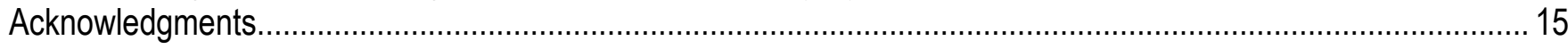

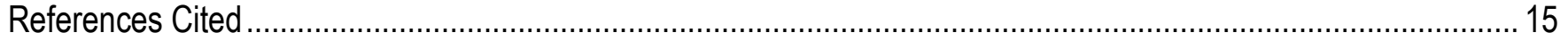

Appendix A. Molecular Genetic Insights into Connectivity between Salmo River Bull Trout and Populations Upstream of Albeni Falls Dam (Priest River, Lake Pend Oreille, Clark Fork River) ............................................... 20

Appendix B. Protocol for Delineating Patches of Suitable Habitat for the Rangewide Bull Trout Vulnerability

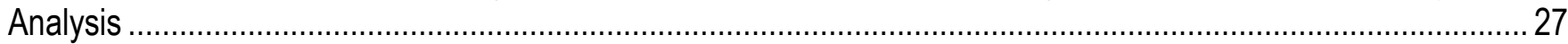

\section{Figures}

Figure 1. Map of the Boundary system, indicating contemporary patches of suitable habitat for bull trout in the Pend Oreille River, northeastern Washington.....

Figure 2. Map of suitable habitat available under a $2^{\circ} \mathrm{C}$ warming scenario in the Boundary system, lower Pend Oreille River, northeastern Washington

Figure 3. Map of suitable habitat available under a $4^{\circ} \mathrm{C}$ warming scenario in the Boundary system, lower Pend Oreille River, northeastern Washington. 


\section{Conversion Factors and Datum}

\section{Conversion Factors}

SI to Inch/Pound

\begin{tabular}{lll}
\hline \multicolumn{1}{c}{ Multiply } & \multicolumn{1}{c}{ By } & \multicolumn{1}{c}{ To obtain } \\
\hline meter $(\mathrm{m})$ & Length & \\
meter $(\mathrm{m})$ & 3.281 & foot $(\mathrm{ft})$ \\
kilometer $(\mathrm{km})$ & 1.094 & yard $(\mathrm{yd})$ \\
\hline & 0.6214 & mile $(\mathrm{mi})$ \\
\hline cubic meter per second $\left(\mathrm{m}^{3} / \mathrm{s}\right)$ & Flow rate & \\
cubic meter per second $\left(\mathrm{m}^{3} / \mathrm{s}\right)$ & 70.05 & acre-feet per day $(\mathrm{acre}-\mathrm{ft} / \mathrm{d})$ \\
cubic meter per second $\left(\mathrm{m}^{3} / \mathrm{s}\right)$ & 35.31 & cubic foot per second $\left(\mathrm{ft}^{3} / \mathrm{s}\right)$ \\
& 22.83 & $\begin{array}{l}\text { million gallons per day } \\
\text { (Mgal } / \mathrm{d})\end{array}$ \\
\hline
\end{tabular}

Temperature in degrees Celsius $\left({ }^{\circ} \mathrm{C}\right)$ may be converted to degrees Fahrenheit $\left({ }^{\circ} \mathrm{F}\right)$ as follows: ${ }^{\circ} \mathrm{F}=\left(1.8 \mathrm{x}^{\circ} \mathrm{C}\right)+32$.

\section{Datum}

Horizontal coordinate information is referenced to the North American Datum of 1983 (NAD 83). 


\title{
Bull Trout in the Boundary System-Managing Connectivity and the Feasibility of a Reintroduction in the Lower Pend Oreille River, Northeastern Washington
}

\author{
By Jason B. Dunham ${ }^{1}$, Eric B. Taylor ${ }^{2}$, and Fred W. Allendorf ${ }^{3}$
}

\section{Introduction}

Many of the World's rivers are influenced by large dams ( $>15 \mathrm{~m}$ high) most of which have fragmented formerly continuous habitats, and significantly altered fish passage, natural flow, temperature, and sediment fluxes (Nilsson and others, 2005; Arthington, 2012; Liermann and others, 2012). In the Pacific Northwest, dams on major rivers have been a major focus for fishery managers, primarily in regard to passage of anadromous salmonids (principally Pacific salmon and steelhead trout [Oncorhynchus mykiss], for example, Ferguson and others, 2011), but more recently other species, such as Pacific lamprey (Entosphenus tridentatus) and resident (non-anadromous) salmonids, are receiving more attention (Neraas and Spruell, 2001; Moser and others, 2002; Muhlfeld and others, 2012). In the case of resident salmonids, fish can adopt a wide range of migratory behaviors that often bring them into mainstem rivers where they can come into direct contact with large dams. When this occurs, some of the most important direct effects of dams on salmonids include barriers to upstream and downstream movement and mortality associated with entrainment within the dam or spill over dams. Biologically, these direct impacts can lead to (1) disruption of natural historical (pre-dam) genetic and demographic connectivity among local populations, (2) loss of access to historically used migratory destinations, (3) loss of individuals to the population through mortality associated with entrainment.

In this report, we address these issues for the case of Boundary Dam, located immediately south of the Canadian border on the lower Pend Oreille River in northeastern Washington (fig. 1).

Specifically, we addressed the following objectives:

- Evaluate the justification for bull trout (Salvelinus confluentus) passing over Boundary Dam in the context of likely historical patterns of gene flow that occurred prior to dam construction, current patterns of movement, and status of existing populations.

- Assess the role of passage over Boundary Dam, in the context of other factors in the system that may influence the feasibility of establishing a self-sustaining bull trout population in the Boundary system.

\footnotetext{
${ }^{1}$ U.S. Geological Survey.

${ }^{2}$ University of British Columbia, Department of Zoology, Biodiversity Research Centre and Beaty Biodiversity Museum.

${ }^{3}$ University of Montana, Division of Biological Sciences.
} 


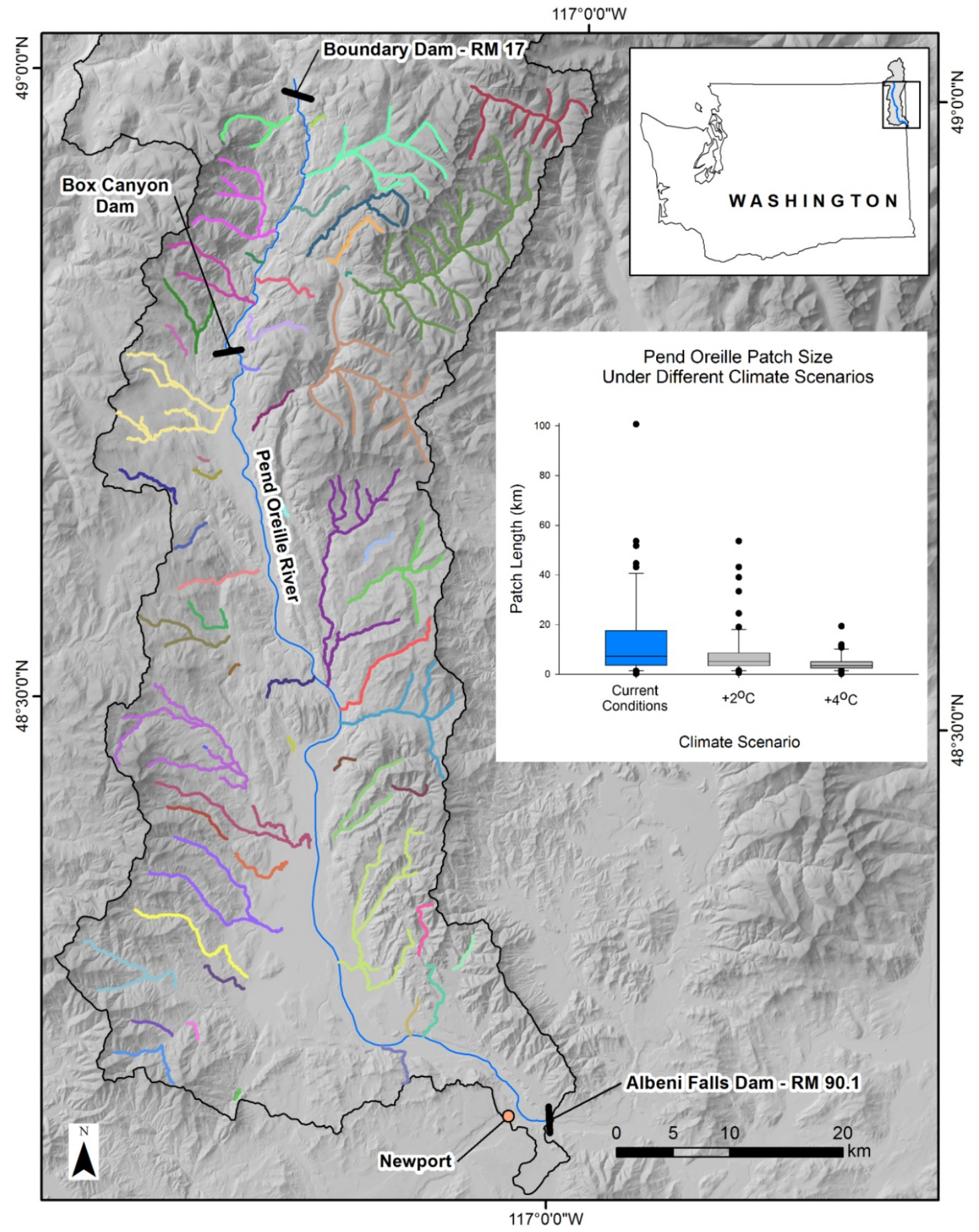

Figure 1. Map of the Boundary system, indicating contemporary patches (see appendix B) of suitable habitat for bull trout in the Pend Oreille River, northeastern Washington. Boxplots indicate available habitat under each scenario (blue highlighted box corresponds to this map). Unique colors for stream lines represent individual patches, with the exception of the mainstem Pend Oreille River, which is not a suitable patch and shown for context only. 


\section{The Boundary System-Synopsis of Relevant Details}

\section{Definition of the Boundary System}

For the purposes of this document, we define the Boundary system as that section of the Pend Oreille River bounded by tailrace of Boundary Dam downstream and upstream by Albeni Falls Dam (fig. 1). Boundary Dam is the main focus herein. It is located on the lower Pend Oreille River near the United States-Canada border, and was constructed in 1967. Additional details on the dam and the Boundary system are available elsewhere (U.S. Fish and Wildlife Service, 2012), and we refer specifically only to those that are directly relevant to our objectives.

\section{Relicensing of Boundary Dam}

In 2012, the U.S. Fish and Wildlife Service issued a Biological Opinion on the proposed relicensing of the Boundary Dam, with a focus on the effects of dam operations on threatened bull trout (U.S. Fish and Wildlife Service, 1999). In addition to the U.S. Fish and Wildlife Service, parties involved in this process included Seattle City Light, the Pend Oreille County Public Utility District, U.S. Forest Service, National Park Service, Bureau of Land Management, Bureau of Indian Affairs, Kalispel Tribe of Indians, Selkirk Conservation Alliance, Washington Department of Fish and Wildlife, Washington State Department of Ecology, the Lands Council, and American Whitewater (U.S. Fish and Wildlife Service, 2012). The Biological Opinion provides a wealth of detail on the issues concerning bull trout in the Boundary System, but the most relevant provisions (with respect to the objectives addressed herein) include the following:

- Evaluation of upstream fish passage over Boundary Dam.

- Restoration of connectivity in tributary systems by removing fish passage barriers.

- Instream and riparian restoration to benefit fish habitat in tributaries.

- Eradication and suppression of non-native salmonids.

- Identification of bull trout habitat that is more likely to be resilient in the face of climate change.

A focal point of uncertainty identified in the Biological Opinion concerns upstream passage over Boundary Dam (U.S. Fish and Wildlife Service, 2012, p. 223):

"Seattle City Light, in coordination with the Service, shall convene an expert scientific panel to review existing bull trout population genetics and life history information with the objective of establishing the natural historical connectivity between Salmo and Lake Pend Oreille bull trout consistent with bull trout recovery goals. The panel will also consider the potential implications to bull trout recovery in the Upper Columbia Headwaters River Recovery Unit ${ }^{4}$ due to passing Salmo River bull trout over Boundary Dam."

This requirement for Seattle City Light, as requested by the U.S. Fish and Wildlife Service, is a major focus of this document. Our review herein begins by directly addressing the issue of passage of bull trout over Boundary Dam, followed by consideration of reintroduction as a means of establishing a self-sustaining population of bull trout in the Boundary system. These topics also cover the two objectives stated in the introduction, which address a slightly broader range of issues than specified directly by the U.S. Fish and Wildlife Service's Biological Opinion.

\footnotetext{
${ }^{4}$ Note that the Boundary system is now classified as part of the Northeast Washington River Areas Recovery Unit (http://www.fws.gov/pacific/bulltrout/Recovery.html).
} 


\section{Passage of Bull Trout over Boundary Dam}

\section{Historical Context of Connectivity between Salmo River and Boundary System Bull Trout}

One of the proposed actions in the Biological Opinion is the upstream passage of bull trout that aggregate in the tailrace of the Boundary Dam such that they might contribute to establishment of a selfsustaining population in the Boundary system. Bull trout in the tailrace originate from at least two known sources - fish that have migrated upstream to the Boundary system from the Salmo River located downstream of the dam (fig. 1) and fish that have passed downstream through the dam and that originated upstream of Albeni Falls Dam (Prince, 2010; U.S. Fish and Wildlife Service, 2012). This section of the report addresses two aspects of the panel's terms of reference (p. 1):

1. An analysis and description of the natural historical connectivity between Salmo River and Lake Pend Oreille bull trout.

2. An analysis and evaluation of passing Salmo River bull trout over Boundary Dam.

\section{Natural Historical Connectivity}

To understand connectivity within the Boundary system, it is important to begin with an understanding of the broader evolutionary history of bull trout. Across their geographic range, bull trout consist of two major evolutionary genetic groups - a coastal and an interior group (Leary and others, 1993; Taylor and others, 1999; Ardren and others, 2011). Bull trout within the Boundary system belong to the interior group, but this group itself is further subdivided into two subgroups (Ardren and others, 2011; DeHaan and others, unpub. data, 2013). One of the subgroups predominates in the upper Kootenai, Blackfoot, Bitterroot, and lower Flathead Rivers, whereas the other subgroup predominates in the Lake Pend Oreille, upper Priest River, and Clark Fork River. Samples from the Pend Oreille River downstream of Boundary Dam and from the South Salmo River were a mixture of both subgroups. Recent analysis of microsatellite loci (appendix A) also suggests that fish sampled from the South Salmo River (but less so for fish from Clearwater Creek, a high gradient tributary of the Salmo River in British Columbia, Canada) show signs of genetic similarity to bull trout from multiple areas upstream of the Boundary system (that is, the Priest/Lake Pend Oreille/Clark Fork, etc.). Previous analyses (for example, Bettles and others, 2005) indicate that the Salmo River system bull trout are highly genetically distinct from areas upstream. Notwithstanding the distinction reported by Bettles and others (2005); when two localities within the Salmo River system (South Salmo River and Clearwater Creek) are considered as distinct localities and analyzed with 12 others from the Priest River/Lake Pend Oreille/Clark Fork River systems; the South Salmo River (and to a much lesser extent Clearwater Creek) show signs of similarity to fish from upstream areas in the Priest River (Uleda Creek and Middle Fork East River) and (to a lesser extent) Lake Pend Oreille (Trestle Creek) systems (appendix A). 
The previously mentioned observations are consistent with the general hypothesis that fish from the Salmo River system and the Boundary system and upstream share a common biogeographic history (that is, they were founded by a closely related set of interior groups). These observations also may suggest that since founding, there has been, at least historically, dispersal and gene flow between the Salmo River and populations within the Boundary system. Analyses of the microsatellite data also indicate that there has been at least some historical gene flow between Salmo River and upstream areas (appendix A). In this sense, the Salmo River and bull trout upstream may have experienced some "evolutionary genetic connectivity." Consequently, at least in terms of evolutionary group (and not necessarily locally adaptive characteristics; Fraser and others, 2011), Salmo River bull trout may be a good evolutionary "match" with fish from areas farther upstream (Dunham and others, 2011). Lowe and Allendorf (2010) noted that genetic connectivity does not imply that the two areas were interconnected in any meaningful demographic (ecological) sense; that is, in that movement of individual bull trout between these two areas was not necessarily significant in terms of sustaining bull trout in either area.

\section{Contemporary Ecological Connectivity}

There are at least two reasons why caution is needed in inferring ecological (or demographic) connectivity from genetic data alone (Lowe and Allendorf, 2010) and in using such data to justify actions to establish connectivity between populations that are now isolated. First, the genetic connectivity (inferred from genetic similarity) may be a remnant signal of historical connectivity that is of little to no relevance in more recent times. For instance, evidence from the microsatellite loci indicates that Clearwater Creek and the South Salmo River are part of the same interior genetic group (and subgroup) (appendix A) which, coupled with their close geographic proximity, also could be interpreted as suggesting current high interlocality dispersal and demographic connectivity. By contrast, when the genetic data are used in a different analysis to actually test for contemporary dispersal between these areas, the two areas in the Salmo River appear to be completely isolated from one another even though they are separated by only about $55 \mathrm{~km}$ (appendix A). By contrast, similar tests for interlocality dispersal suggest extensive contemporary movement between the Middle Fork East River and one of its tributary streams, Uleda Creek (both also of the same interior subgroup), of the Priest River system, which are only a few kilometers from one another. Consequently, contemporary isolation-by-distance can greatly modify historical genetic connectivity (appendix A). Second, demographic connectivity depends on the proportion of fish in an area that are immigrants from another area whereas evolutionary genetic connectivity depends on the absolute number of individuals exchanged (Allendorf and Phelps, 1981). Consequently, only a small number of individuals moving between localities (one in the extreme case, Lowe and Allendorf, 2010) may result in some non-zero estimate of evolutionary genetic connectivity (for example, indirect measures such as the fixation index $\left(F_{S T}\right)$ - the proportion of total variance in allele frequencies attributable to differences between localities) that may have little to no meaning demographically. Stated another way, any given measure of genetic connectivity derived by collecting data, such as microsatellite allele frequencies and calculating $F_{S T}$, can be observed under entirely different demographic scenarios (for example, different effective population sizes $\left(N_{e}\right)$ and interpopulation migration rates ( $m$, see appendix A and Lowe and Allendorf, 2010). The take away message is that without reasonable estimates of critical demographic parameters (such as $N_{e}$ ) for potentially interacting populations, indirect inferences of demographic connectivity based on genetic estimates of similarity (such as by $F_{S T}$ ) are problematic. Furthermore, even direct estimates of connectivity using genetic data (for example, by individual genetic assignment methods) are difficult to relate to demographic connectivity without an understanding of how such immigrants contribute, or if they even do, to vital rates of recipient populations (Lowe and Allendorf, 2010). Consequently, if 
passage of fish upstream (or downstream) of the Boundary Dam was initiated, it would be important to physically tag each fish and obtain tissue samples for DNA analysis, such that the potential demographic or genetic contribution of these fish to recipient populations could be investigated.

Looking beyond inferences based on molecular genetic markers, it also is important to note the existence of two geomorphological barriers to upstream movement from the Salmo River into the Boundary system, as noted in the Biological Opinion (U.S. Fish and Wildlife Service, 2012, p. 164):

"Bull trout that originate downstream of Boundary Dam would come from the Salmo River, a tributary to the Pend Oreille River approximately 4.3 miles downstream of Boundary Dam.

Historically, Salmo River bull trout are thought to have been able to migrate upstream to Metaline Falls (USFWS 2002; Gillin and Pizzimenti 2004; DeHaan and Ardren 2007). Metaline Falls and Z Canyon are thought to have been significant obstacles for migratory fish. Anadromous species were restricted to the lower Pend Oreille River (below Metaline Falls), but Metaline Falls and Z Canyon are not entirely impassable (Gilbert and Everman 1895; DeHaan and Ardren 2007)."

The influence of these barriers in the system and patterns of molecular genetic variability within the Boundary system are consistent with the interpretation that, before construction of the Boundary Dam completely eliminated the possibility of movement upstream past the dam, gene flow and demographic support were both almost surely limited in their extent and significance in the Boundary system - at least with respect to the question of connectivity between the Salmo River and populations of bull trout upstream.

In summary, the available molecular genetic data clearly indicate a common or nearly common historical origin for bull trout in the Salmo River drainage and those in upstream areas of the Boundary system and Pend Oreille River Basin. These same data also indicate that the Salmo River is currently highly genetically isolated from fish upstream in the Boundary system and farther upstream areas of the Pend Oreille River Basin. Certainly, a high degree of population genetic divergence is commonly encountered in bull trout complexes (Leary and others, 1993; Costello and others, 2003). Simulations under a model of complete isolation indicate that the current mean level of genetic subdivision between the Salmo River and upstream areas $\left(F_{S T}=0.17\right)$ is highly unlikely to have arisen since the closure of the Boundary Dam in 1966 (about 10 generations, appendix A) implying that the present degree of genetic distinction is not an artifact of dam construction. Even within the Salmo River system, genetic divergence is high; the South Salmo River and Clearwater Creek differed by $F_{S T}=0.12$; and there are no known migration barriers between these spawning areas. The natural evolution of genetic differentiation between the Salmo River system and upstream areas is further supported by the greater distance between them and the presence of physical movement barriers in the Boundary system that existed prior to dam construction. Genetic measures of connectivity are difficult to relate directly to demographic connectivity without much more detailed information on actual fish movement and the fates of interpopulation dispersers. Consequently, there is no compelling evidence that bull trout from the Salmo River have historically interacted with fish from upstream areas in any way that would have been significant to the persistence of bull trout in the Boundary system or farther upstream. The weight of evidence from the preceding analyses indicates that passage of bull trout in the tailrace of Boundary Dam upstream over the dam as a way of "reconnecting" the historically interacting populations is not supported from what we can infer about the biology of the system. If, despite these findings, a management decision is made to allow for upstream passage of bull trout originating from upstream over Boundary Dam, it would be important to provide real-time genetic analyses (DeHaan and others, 2011) to ensure the origins of fish passing over the dam are known. 


\section{Feasibility of Establishing Bull Trout in the Boundary System}

Passage of bull trout over the Boundary Dam is an important issue in itself, but we decided to additionally consider passage within the broader context of the larger goal of establishing a selfsustaining population of bull trout in the Boundary system. This is important to address the broader objective of contributing to recovery of bull trout in general (U.S, Fish and Wildlife Service, 2002). Although records show that local populations of bull trout likely existed in the system prior to dams, there are no known self-sustaining populations extant between Albeni Falls Dam and Boundary Dam (U.S. Fish and Wildlife Service, 2012). Re-establishment of a self-sustaining population of bull trout could be realized through natural recolonization or by active means (transfer of fish from outside of the Boundary system).

The probability that natural recolonization will establish a self-sustaining population of bull trout in the Boundary system seems low, based on several lines of evidence. Our finding of low levels of contemporary gene flow and the existence of pre-dam barriers to upstream movement provide little support for an ecologically significant connection between the Salmo River downstream and the Boundary system. It also seems unlikely that sufficient numbers of colonists will arrive from sources upstream of Albeni Falls Dam (U.S. Fish and Wildlife Service, 2012, p. 125). Although numbers of bull trout entering the Boundary system from the Priest River and Lake Pend Oreille systems are low at present ( $<10$ fish per year), construction of passage facilities at upstream dams (Albeni Falls and Box Canyon) by 2025 may improve the chances of natural recolonization in the future (U.S. Fish and Wildlife Service, 2012). Even if passage is restored, however, the presence of natural upstream movement barriers in tributaries to the Boundary system; their distance from extant sources of colonists; and the currently depressed status of many of the upstream sources indicates that natural recolonization is unlikely. The propensity of bull trout to exhibit strong natal homing may further reduce the probability of natural recolonization. In addition to upstream dams, isolation of the Boundary system may be further exacerbated by an increasing number of nonnative fish that have colonized and expanded throughout the Boundary system (Sanderson and others, 2009; U.S. Fish and Wildlife Service, 2012).

Given the previously mentioned conditions, if a self-sustaining population is to be established in the short term (within the next 10-20 years), a more active approach to reintroduction may be warranted. This would involve the transfer of fish from a donor population to a suitable location within the Boundary system with the expectation that those fish would establish a self-sustaining population. Before such an effort is attempted, it is worthwhile to consider the feasibility of reintroduction (Dunham and others, 2011). Here we follow the framework proposed by Dunham and others (2011; with additional modifications) to evaluate the case for reintroduction in the Boundary system.

The framework described by Dunham and others (2011) involves an assessment of several different elements that can drive the success of a reintroduction, including:

- Evaluation of the probability that a given location was occupied historically;

- Determination that natural recolonization is unlikely;

- Assessment of the suitability of current and future habitat conditions; and

- Evaluation of the suitability of alternative donor populations to serve as a source of individuals for a reintroduction. 
Here we provide additional consideration of the potential influences of nonnative salmonids, namely brook trout (Salvelinus fontinalis), as this species may pose significant threats to bull trout in the Boundary system. We also provide a more explicit consideration of the effects of climate change on spawning and early rearing habitats for bull trout in the system. These are discussed in turn below. Ultimately, a more formal process beyond the scope of this work may be warranted as the decision to conduct a reintroduction involves an investment of a large amount of resources over many years. Currently an estimate for the annual cost of the Clackamas River bull trout reintroduction is approximately \$250,000 USD per year (Chris Allen, U.S. Fish and Wildlife Service, oral commun., 2014).

\section{Historical Occupancy and Likelihood of Natural Recolonization}

The considerations for reintroductions mentioned in the preceding section were discussed previously in reference to the Boundary system. Based on existing evidence, it is likely that bull trout had historically established self-sustaining populations in one or more of the tributaries to the Boundary system, and it is unlikely in the near future that recolonization will occur without active assistance (that is, transferring fish into the Boundary system from a donor population outside of the system).

\section{Current and Future Habitat Suitability}

Based on our habitat mapping procedure (appendix B) we identified stream networks that are currently suitable for bull trout in the Boundary system (fig. 1). Results indicated widespread availability of suitable habitat in the basin, including a few relatively large stream networks with more than $40 \mathrm{~km}$ of available habitat. Because our habitat mapping procedure relied strongly on temperature, we evaluated the potential effects of climate change on availability of suitable habitat. To do so, we modeled incrementally increasing water temperatures by $2-4{ }^{\circ} \mathrm{C}$ to evaluate potential loss of habitats. This level of increase is based on analyses of climate warming in streams across the Western United States (Arismendi and others, 2012; Isaak and others, 2012), although these studies are based on limited data. Furthermore, many of the required habitat restoration actions in the Boundary system may offset the effects of climate change by restoring instream flow and riparian shading, both of which should be expected to result in lower stream temperatures. In any case, it is useful to evaluate potential climate warming scenarios, even if we cannot precisely predict what will happen in the future at this point. Increases of $2{ }^{\circ} \mathrm{C}$ across all stream reaches resulted in a substantial contraction of available habitat (fig. 2) but larger ( $>40 \mathrm{~km}$ of available habitat) patches were still available. Doubling the temperature increase to $4{ }^{\circ} \mathrm{C}$ above contemporary stream temperatures resulted in reducing all patch sizes to less than $20 \mathrm{~km}$ of suitable stream habitat (fig. 3).

Temperature is not the only important change expected with climate change. Other effects of climate change may be important, and were not considered here, namely the possibility of lower low flows (Stewart and others, 2005; Luce and Holden, 2009; Luce and others, 2013) and increasing probability of winter flooding (Wenger and others, 2011). Although these impacts from climate change may be important, previous work considering these variables was based on presence of bull trout at sites (Wenger and others, 2011), and we assumed here broader changes in fragmentation of habitat (for example, patch size and connectivity, as driven by availability of cold water) are higher order controls on the persistence of bull trout (Dunham and Rieman, 1999; Dunham and others, 2002b). In forthcoming work, we will better understand the role of hydrological variability in driving the presence of bull trout in patches, as opposed to sites (by means of the Rangewide Bull Trout Vulnerability Assessment, http://www.doi.gov/csc/northwest/news/research-highlight-vulnerability-assessment-forthreatened-bull-trout.cfm). 


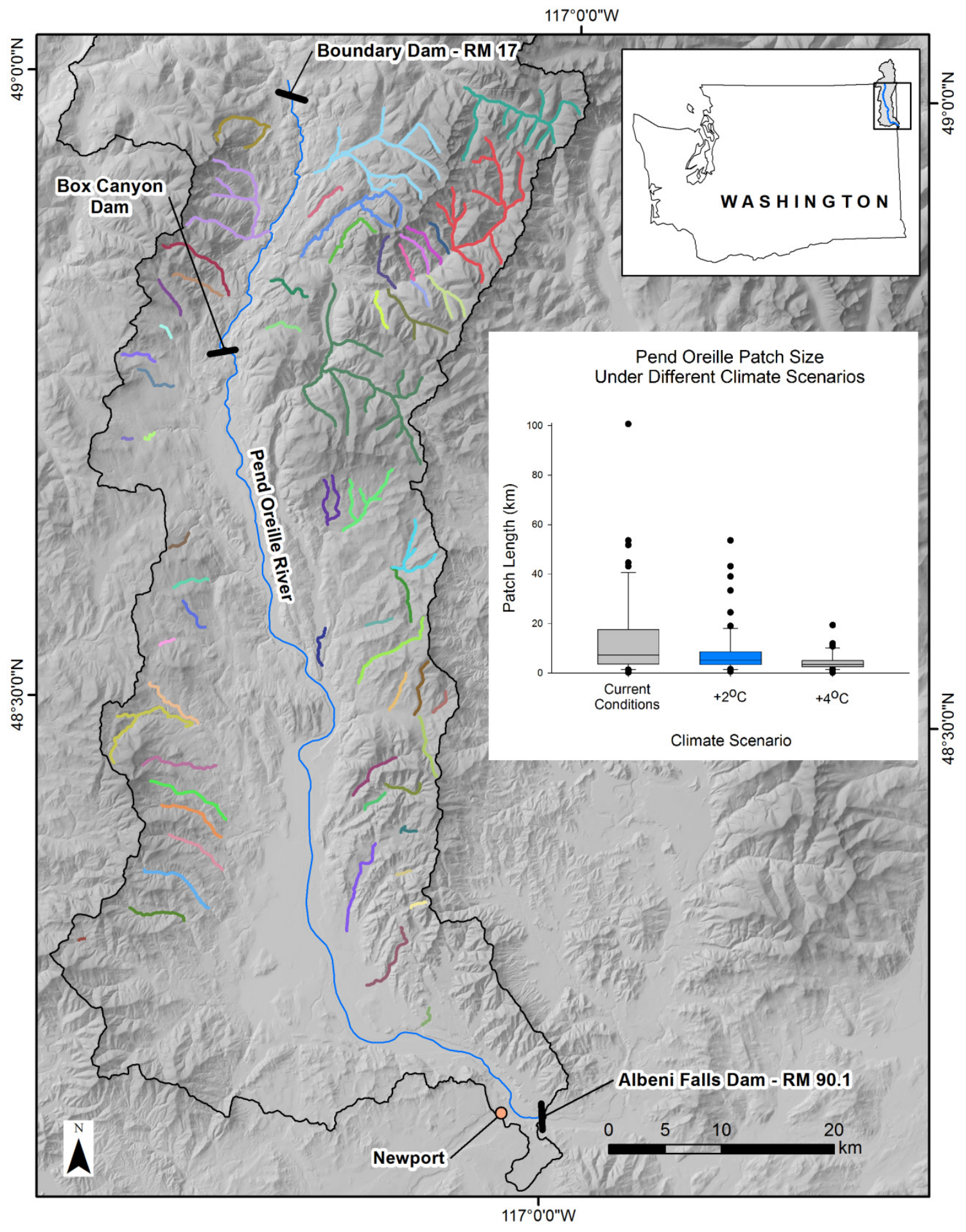

Figure 2. Map of suitable habitat available under a $2{ }^{\circ} \mathrm{C}$ warming scenario in the Boundary system, lower Pend Oreille River, northeastern Washington. Boxplots indicate available habitat under each scenario (blue highlighted box corresponds to this map). Unique colors for stream lines represent individual patches, with the exception of the mainstem Pend Oreille River, which is not a suitable patch and shown for context only. 


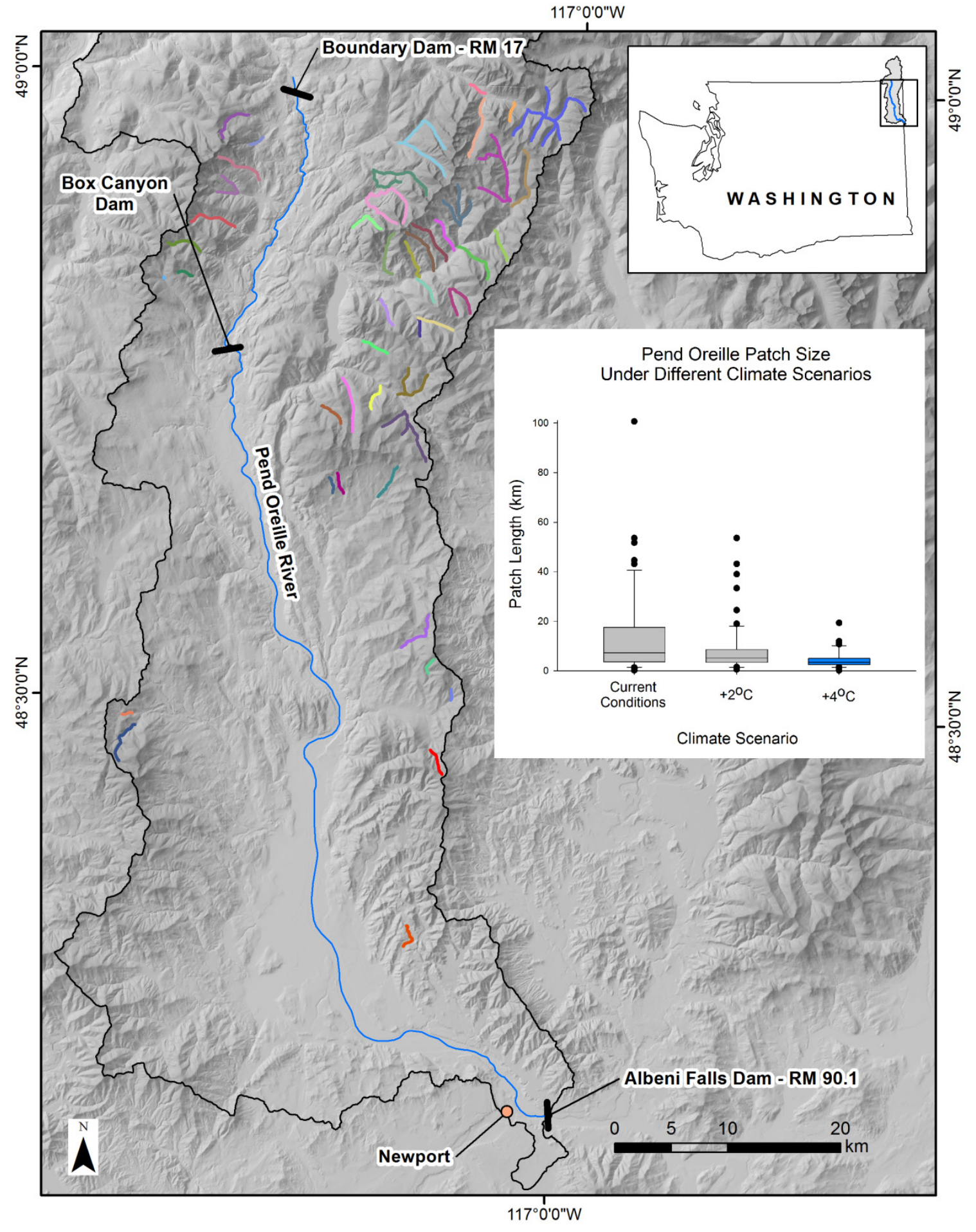

Figure 3. Map of suitable habitat available under a $4^{\circ} \mathrm{C}$ warming scenario in the Boundary system, lower Pend Oreille River, northeastern Washington. Boxplots indicate available habitat under each scenario (blue highlighted box corresponds to this map). Unique colors for stream lines represent individual patches, with the exception of the mainstem Pend Oreille River, which is not a suitable patch and shown for context only. 


\section{Threats from Nonnative Brook Trout}

Although several species of nonnative fishes may pose threats to bull trout, nonnative brook trout is the most relevant within the Boundary system. Nonnative brook trout are well-established throughout tributaries to the Boundary system (McLellan, 2001; Andonaegui, 2003). Although nonnative brook trout sometimes hybridize with or have adverse ecological effects on bull trout (U.S. Fish and Wildlife Service, 2002), it is difficult to predict the outcomes of species interactions on a local level. A recent large-scale analysis of the effects of brook trout on bull trout presence at sites throughout the upper Columbia River basin revealed only weak effects (decreased probability of presence; Wenger and others, 2011), with studies distributed across Washington yielding similar results (Dunham and others, 2003). In spite of the generally weak relationship between brook trout and bull trout, it is possible that threats from brook trout could be greater in some locations within the Boundary system. Greater effects seem likely in the Boundary system relative to other areas where established populations of bull trout may have some resistance to brook trout invasion, simply because bull trout have already been replaced by brook trout.

Although we have a poor understanding of factors that mediate interactions between brook and bull trout, it is reasonable to hypothesize that several factors may increase resistance of bull trout populations to brook trout invasion, including: populations that occupy very cold systems (less suitable physiologically for brook trout); populations that express a strong migratory life history (which is not strongly expressed in nonnative brook trout; Dunham and others, 2002a); or populations of bull trout with high densities of individuals. Measures taken to control brook trout in the Boundary system (U.S. Fish and Wildlife Service, 2012) may be needed at least in the initial (pre-establishment) phases of a bull trout reintroduction to ensure that a self-sustaining population is established. Complete control of brook trout in the Boundary system is unlikely without major investments (Buktenica and others, 2013). Even if control is successful in the short term, over the long term, the possibility of unauthorized reintroductions of brook trout could be problematic (Rahel, 2004). Ultimately, the long-term success of a reintroduction may be more dependent on maintaining conditions that are believed to confer an ecological advantage to bull trout, relative to brook trout. This has been termed "managing for coexistence" in the case of brook trout (Dunham and others, 2002a). Because we understand little about the feasibility of this alternative, future study or focused monitoring may be warranted to evaluate the assumptions (hypotheses) behind it.

\section{Suitability of Available Donor Populations}

Suitability of donor populations for a reintroduction is conditioned on several factors, including (1) a sufficiently close evolutionary genetic match to the recipient system; (2) sufficient numbers of individuals to support a reintroduction; (3) lack of parasites, disease, or other factors that would be undesirable to introduce to the recipient habitat. Here we consider the possibility of suitable donor populations upstream and downstream of the Boundary system.

Downstream of the Boundary system, the only available donor population of bull trout is represented by the Salmo River. Although Salmo River bull trout share a common evolutionary history with bull trout upstream in the Boundary system (that is, connectivity on a timescale of $>10^{3}$ years), as previously detailed, it is unlikely that Salmo River bull trout have contributed genetically or demographically to populations upstream in more contemporary $\left(<10^{3}\right.$ years $)$ time frames. Accordingly, as previously emphasized, passage of bull trout from the Salmo River upstream over the Boundary Dam would represent movement of fish that was not likely to occur to any demographically significant degree prior to dam construction. 
Whereas many bull trout populations may be considered to share a common evolutionary history, local populations often lack sufficient numbers of individuals available to support a reintroduction, as seems likely in the case of the Salmo River. Using guidelines discussed by Rieman and Allendorf (2001), Dunham and others (2011) suggested that no donor population should be considered unless it had at least 1,000 spawners in any given year. More recently, Frankham and others (2014) suggested that the "50:500" rule for minimum effective population size, upon which the 1,000 spawners per year idea is largely based, may be too liberal for protection both of short-term levels of genetic diversity and long-term evolutionary potential of populations (that is, minimum sizes of donor populations should be even higher). Regardless of the exact value of proposed threshold values, the estimated population size of the Salmo River population is far below such proposed thresholds. Twelve years of redd count data (1998-2009) suggest that this index of the number of spawners in the Salmo River system is generally low and fluctuated between 38 and 109 redds per year (Hagen and Decker, 2011). Actual population sizes were estimated at fewer than 50 to as many as 250 adults, with a decreasing trend through time (Hagen and Decker, 2011). Further, the Salmo River population is one of the five core areas for bull trout in the upper Columbia-Arrow Ecological Drainage Unit (British Columbia categorization) and was assessed an overall status of "High Risk" given low population sizes and risk factors (water temperatures, degraded habitats, and brook trout hybridization and displacement) that were considered to be high to moderate for scope, severity, and immediacy. Hagen and Decker (2011) concluded that the Salmo River population was one of the "most threatened bull trout populations" (ranking system based on U.S. Fish and Wildlife Service, 2005; Committee on the Status of Endangered Wildlife in Canada, 2012) in British Columbia. Finally, Prince (2010) documented the presence of seven bull trout that were radio-tagged in the Salmo River and tracked to the tailrace of the Boundary Dam. Such observations may suggest a degree of historical demographic interconnectedness between the Salmo River and areas upstream in the Boundary system and could be used as a rationale for passing Salmo River fish upstream of Boundary Dam. The fish tracked by Prince (2010), however, were subadult fish, not mature adults, and subadults are well known to make foraging movements from tributaries to lakes or larger rivers before returning to tributaries to spawn (Taylor and others, 2014). Consequently, the passage of pre-reproductive, foraging bull trout upstream of the Boundary Dam would eliminate the possibility that they could successfully return back downstream and spawn in their natal Salmo River, which would put further pressure on an already at-risk population (notwithstanding occasional survival of adults that move downstream through Boundary Dam; Prince, 2010). At the risk of some stress imposed on fish downstream of the spillway, it is possible that a sorting facility could use real-time DNA assays to identify Salmo River fish and pass only fish that could be confidently identified as originating from upstream areas (Nerass and Spruell, 2001). Further, while it is possible that not passing all fish upstream (or downstream of Boundary Dam) may limit foraging opportunities in the Boundary system, we have previously argued that use of these upstream areas was likely minor and that the risks of upstream or downstream passage, therefore, likely outweigh any potential benefits. Fish not passed upstream of Boundary Dam possibly could be susceptible to entrainment at the Seven Mile and Waneta Dams downstream of Boundary Dam. 
In an upstream direction, the possibility of available donors for reintroduction from populations upstream of the Boundary system seems much more likely. According to the most recent review of the status of bull trout in the United States (U.S. Fish and Wildlife Service, 2008), a conservative estimate of the number of adult bull trout in the Lake Pend Oreille Core Area indicates at least 2,500 fish; and that numbers in the system appear stable and threats to bull trout are considered to be moderate and nonimminent. Fish from this Core Area currently contribute the limited number of bull trout that do enter the Boundary system from upstream. Outside of the Pend Oreille Core Area, upstream prospects for additional candidate donor populations for a possible reintroduction into the Boundary system seem less likely. For example, in the Priest Lake Core Area, numbers of adult bull trout are low $(<250$ individuals), declining, and facing substantial and imminent threats. Populations upstream of Lake Pend Oreille (for example, Clark Fork system) are more evolutionarily divergent and generally more at risk relative to the Lake Pend Oreille Core Area (U.S. Fish and Wildlife Service, 2008). Evaluation of more recent information on these potential donor populations is warranted if a decision is made to consider the feasibility of a reintroduction.

A final consideration that is often invoked in the case of bull trout is migratory behavior. As with many salmonid fishes, bull trout exhibit "partial migration," a condition whereby some individuals complete their life cycles within their natal stream; whereas others migrate to migratory destinations, such as large rivers, lakes, reservoirs, and marine habitats (Dodson and others, 2013). Various naming conventions, based on alternative destinations of migratory individuals, have been applied. Within freshwaters, migratory individuals have been classified as potamodromous (Myers, 1949). Various terms applied within this class of migrations include fluvial (residents that complete their life cycle within a limited home range), fluvial-adfluvial (migrations from rivers into tributaries to spawn), lacustrine-adfluvial (migrations from lakes into upstream tributaries to spawn), and allacustrine (migration from lake into lake outlets to spawn or access spawning tributaries; Varley and Gresswell, 1988). Each of these behaviors are known to be expressed in bull trout and other closely related charrs, although the diversity of habitats used by these species can defy simple classification (Dunham and others, 2008) and individuals can exhibit different migratory behaviors within their lifetime (Armstrong and Bond, 2013). Furthermore, it is clear from research on a variety of salmonids, including charrs, that genetic divergence between individuals expressing different migratory behaviors in partially migratory species is generally low to non-existent, and thus different behaviors can emerge from common gene pools (Dodson and others, 2013). Expression of diversity of migratory behaviors in bull trout and similar species is highly plastic. In terms of selection of a donor population, this means that fish within receiving habitats may adopt migratory behaviors that are different from the donor. There are few examples for the case of bull trout in particular, but the case of reintroduction into the Clackamas River is instructive. In this case, bull trout from populations with strong expression of lacustrine-adfluvial life behavior (the Metolius River) were translocated into the upper Clackamas River to re-establish a selfsustaining population (Barry and others, 2014). Unlike the donor source, few of the translocated individuals exhibited lacustrine-adfluvial migrations, with the vast majority exhibiting fluvial-adfluvial (riverine migration and tributary spawning) behaviors. This finding, although from a case study, is arguably not different than may be expected given the well-known flexibility of migratory behavior in charrs. 
In summary, the proposed action of passing Salmo River bull trout upstream of the Boundary Dam in an attempt to contribute to the re-establishment of bull trout in the Boundary system is not biologically justifiable because (1) existing evidence casts doubt on the likelihood that there was a significant degree of demographic connectedness between Salmo River and bull trout populations in the Boundary system prior to construction of Boundary Dam and (2) passage upstream of Boundary Dam of even a small number of fish that originated in the Salmo River would contribute to increasing the risk to the persistence of bull trout in the Salmo River, which already has a current conservation status of "High Risk." Similarly, upstream passage of bull trout in the tailwater of Boundary Dam is not warranted for fish that originated upstream, because upstream passage was unlikely before the dam was constructed. This is due to the low probability of fish naturally returning upstream over natural barriers (waterfalls) that were historically present in the system. In short, there is no compelling evidence to indicate that passage of bull trout, regardless of population origin, over Boundary Dam is warranted. In contrast, populations of bull trout upstream of the Boundary system offer some opportunity to serve as a donor for a potential reintroduction, if considered as a means of establishing a self-sustaining population of bull trout. Additional evaluation of potential donor populations would be warranted (for example, screening for pathogens, selection of life stages to utilize, etc.; Dunham and others, 2011) if a reintroduction is to be more comprehensively evaluated in the future.

\section{Conclusions and Recommendations}

With respect to the stated objectives of this review and our interpretation of the intent of U.S. Fish and Wildlife Service's Biological Opinion (U.S. Fish and Wildlife Service, 2012), we offer the following conclusions, based on our review of the best available scientific evidence.

\section{Evaluation of Passing Bull Trout over Boundary Dam}

Our review of likely historical patterns of gene flow that occurred prior to construction of Boundary Dam, current patterns of movement, and the status of existing populations all suggest that passage of bull trout over Boundary Dam, regardless of direction (upstream or downstream) or origin (bull trout from the Salmo River or upstream of the Boundary system) offers limited opportunity to benefit bull trout in the Boundary system. Upstream passage of Salmo River bull trout in particular may pose significant risks to persistence of bull trout in the Salmo River immediately downstream (compare discussion in Nerass and Spruell, 2001, and DeHaan and others, 2011, with respect to passing fish upstream of the Cabinet Gorge Dam). In this regard, all available lines of evidence are in agreement.

\section{Establishing a Self-Sustaining Population in the Boundary System}

In the broader context of recovery of bull trout in the Upper Columbia River Recovery Unit and lower Pend Oreille Core Area in particular (U.S. Fish and Wildlife Service, 2002, 2008), establishing a self-sustaining population represents a fundamental goal (U.S. Fish and Wildlife Service, 2012). The most likely means of attaining this goal within the foreseeable future is through a more detailed consideration of the feasibility of a reintroduction. Although the essential elements that contribute to the potential feasibility of a reintroduction are present in the Boundary system (that is, there is no evidence to conclusively exclude reintroduction as an alternative), a more formal and comprehensive evaluation is needed. In this regard, the major uncertainties we identified were linked to effectiveness of proposed 
actions to restore physical habitat conditions and control nonnative brook trout in tributary systems; the future effects of climate change on availability of suitable spawning and rearing habitats; and availability of a suitable donor population for a potential reintroduction. With respect to Boundary Dam, we found no evidence to indicate that passage of bull trout over the dam will contribute significantly to the likelihood of establishing a self-sustaining population of bull trout in the Boundary system.

More generally, we find significant opportunity to improve the quality of conditions for coldwater species and bull trout in particular, in the tributaries of the Boundary system. Additional work would provide a more comprehensive assessment of opportunities and the likelihood that any resulting actions would succeed in the face of climate change. Managing passage over Boundary Dam, however, is unlikely to improve the status of bull trout in the Boundary system and may pose substantial risks to other affected populations (for example, Salmo River). Although many of the actions in tributary habitats specified in the U.S. Fish and Wildlife Service's Biological Opinion (U.S. Fish and Wildlife Service, 2012) appear promising, linking them more directly to the goal of establishing a self-sustaining population of bull trout in the Boundary system and a more formal evaluation of management alternatives seems warranted, given the large investment at stake and pervasive uncertainties about their likelihood of success.

\section{Acknowledgments}

David Hockman-Wert and Michael Heck of the U.S. Geological Survey, Forest and Rangeland Ecosystem Science Center, assisted with development of patch protocols, analysis, and maps displayed herein. NorWeST stream temperature predictions were produced through an effort led by Dan Isaak of the U.S. Forest Service, Rocky Mountain Research Station, Boise Aquatic Sciences Laboratory. We thank Bill Ardren and Patrick DeHaan of the US Fish and Wildlife Service for making their microsatellite data available for analyses. Discussions with Andrew Bearlin, Harry Rich, and Al Solonsky of Seattle City Light, as well as Erin Britton Kuttel of U.S. Fish and Wildlife Service were essential to developing this document.

\section{References Cited}

Allendorf, F.W., Luikart, G., and Aitken, S.N., 2013, Conservation and the genetics of populations (2d ed.): Chichester, United Kingdom, Wiley-Blackwell Publishing, 602 p.

Allendorf, F.W., and Phelps, S.R., 1981, Use of allelic frequencies to describe population structure:

Canadian Journal of Fisheries and Aquatic Sciences, v. 38, p. 1507-1514.

Andonaegui, C., 2003, Bull trout habitat limiting factors for Water Resource Inventory Area (WRIA) 62 (Pend Oreille County, Northeast Washington State): Olympia, Washington, Washington State Conservation Commission.

Ardren, W.R., DeHaan, P.W., Smith, C.T., Taylor, E.B., and others, 2011, Genetic structure, evolutionary history, and conservation units of bull trout in the coterminous United States, Transactions of the American Fisheries Society, v. 140, p. 506-525.

Arismendi, I., Johnson, S.L., Dunham, J.B., Haggerty, R., and Hockman-Wert, D., 2012, The paradox of cooling streams in a warming world: regional climate trends do not parallel variable local trends in stream temperature in the Pacific continental United States: Geophysical Research Letters, v. 39, p. L10401, DOI: 10.1029/2012GL051448.

Armstrong, J.B., and Bond, M.H., 2013, Phenotype flexibility in wild fish-Dolly Varden regulate assimilative capacity to capitalize on annual pulsed subsidies: Journal of Animal Ecology, v. 82, p. 966-975. 
Arthington, A.H., 2012, Environmental flows-Saving rivers in the third millennium: Oakland, Calif., University of California Press, 464 p.

Barry, P.M., Hudson, J.M., Williamson, J.D., Koski, M.L., and Clements, S.P., 2014, Clackamas River Bull Trout Reintroduction Project, 2013 Annual Report: Oregon Department of Fish and Wildlife and U.S. Fish and Wildlife Service, $46 \mathrm{p}$.

Beerli, P., 2012, Migrate-N documentation, version 3.6.4.: Florida State University, Department of Scientific Computing, http://popgen.sc.fsu.edu/Migrate/Migrate-n.html.

Bettles, C.M., Von Bargen, J., and Young, S., 2005, Microsatellite DNA characterization of selected bull trout (Salvelinus confluentus) populations within the Pend Oreille River Basin: Washington Department of Fish and Wildlife, Conservation Biology Unit, Genetics Lab, June 2005.

Buktenica, M.W., Hering, D.K., Girdner, S.F., Mahoney, B.D., and Rosenlund, B.D., 2013, Eradication of nonnative brook trout with electrofishing and antimycin-A and the response of a remnant bull trout population: North American Journal of Fisheries Management, v. 33, p. 117-129.

Committee for the Status of Endangered Wildlife in Canada, 2012, Status report and assessment for Bull Trout (Salvelinus confluentus) in Canada: Committee for the Status of Endangered Wildlife in Canada, Canadian Wildlife Service, Ottawa, www.sarapublicregistry.gc.ca.

Costello, A.B., Down, T.E., Pollard, S.M., Pacas, C.J., and Taylor. E.B., 2003, The influence of history and contemporary stream hydrology on the evolution of genetic diversity within a species: an examination of microsatellite DNA variation in bull trout, Salvelinus confluentus (Pisces:

Salmonidae): Evolution, v. 57, 2003, p. 328-344.

DeHaan, P.W., and Ardren, W.R., 2007, Expanding the Lake Pend Oreille and Clark Fork River bull trout genetic baseline by adding populations from the Pend Oreille River Basin: Abernathy fish Technology Center, Final Report to Joseph Maroney, Kalispel Tribe.

DeHaan, P.W., Bernall, S.R., DosSantos, J.M., Lockhard, L.L., and Ardren, W.R., 2011, Use of genetic markers to aid in re-establishing migratory connectivity in a fragmented metapopulation of bull trout (Salvelinus confluentus): Canadian Journal of Fisheries and Aquatic Sciences, v. 68, p. 1952-1969.

Dunham, J.B., and Rieman, B.E., 1999, Metapopulation structure of bull trout-Influences physical, biotic, and geometrical landscape characteristics: Ecological Applications, v. 9, p.642-655.

Dodson J.J., Aubin-Horth, N., Theriault, V., and Paez, D., 2013, The evolutionary ecology of alternative migratory tactics in salmonid fishes: Biological Review, v. 88, no. 3, p. 602-625, doi: 10.111/brv.12019.

Dunham, J., Adams, S.B., Schroeter, R., and Novinger, D., 2002a, Alien invasions in aquatic ecosystems-Toward an understanding of brook trout invasions and their potential impacts on inland cutthroat trout in western North America: Reviews in Fish Biology and Fisheries, v. 12, p. 373-391.

Dunham, J.B., Rieman, B.E., and Peterson, J.T., 2002b, Patch-based models of species presenceLessons from salmonid fishes in streams, in Scott, J.M., and others, eds., Predicting species occurrences-Issues of accuracy and scale: Covelo, California, Island Press, p. 327-334.

Dunham, J., Rieman, B., and Chandler, G., 2003, Influences of temperature and environmental variables on the distribution of bull trout within streams at the southern margin of its range: North American Journal of Fisheries Management, v. 23, p. 894-904.

Dunham, J.B., Baxter, C.V., Fausch, K.D., Fredenberg, W., Kitano, S., Koizumi, I., Morita, K., Nakamura, T., Rieman, B.E., Savvaitova, K., Stanford, J., Taylor, E., and Yamamoto, S., 2008, Evolution, ecology, and conservation of Dolly Varden, white-spotted char, and bull trout: Fisheries v. 33 , no. 11, p. 537-550. 
Dunham, D., Gallo, D., Shively, D., Allen, C., and Goehring, B., 2011, Assessing the feasibility of native fish reintroductions-A framework applied to threatened bull trout: North American Journal of Fisheries Management, v. 31, p. 106-115.

Evanno, G., Regnaut, S., and Goudet, J., 2005, Detecting the number of clusters of individuals using the software STRUCTURE: a simulation study: Molecular Ecology, v. 14, p. 2611-2620.

Falush, D., Stephens, M., and Pritchard, J.K., 2003, Inference of population structure: Extensions to linked loci and correlated allele frequencies: Genetics, v. 164, p.1567-1587.

Ferguson, J.W., Healey, M., Dugan, P., and Barlow, C., 2011, Potential effects of dams on migratory fish in the Mekong River-Lessons from salmon in the Fraser and Columbia Rivers: Environmental Management, v. 41, p. 141-159.

Fraser, D. J., Weir, L. K., Bernatchez, L., Hansen, M. M., and Taylor, E. B., 2011, Extent and scale of local adaptation in salmonid fishes: review and meta-analysis. Heredity, v. 106, p. 404-420.

Frankham, R., Bradshaw, C.J.A., and Brook, B.W., 2014, Genetics in conservation managementRevised recommendations for the 50/500 rules, Red List criteria and population viability analyses: Biological Conservation, v. 170, p. 56-63.

Hagen, J., and Decker, S., 2011, Bull trout population 'health' in British Columbia-Distribution, abundance, trends and threats: Victoria, British Columbia, Canada, British Columbia Ministry of Environment, $104 \mathrm{p}$.

Hastings, A., 1993, Complex interactions between dispersal and dynamicslessons from coupled logistic equations: Ecology, v. 74, p. 1362-1372.

Isaak, D.J., Wollrab, S., Horan, D., and Chandler, G.L., 2012, Climate change effects on stream and river temperatures across the northwest U.S. from 1980-2009 and implications for salmonid fishes: Climatic Change, v. 113, p. 499-524.

Leary, R.F., Allendorf, F.W., and Forbes, S.H., 1993, Conservation genetics of bull trout in the Columbia and Klamath River drainages: Conservation Biology, v. 7, p. 856-865.

Liermann, C.R., Nilsson, C., Robertson, J., and Ng, R.Y., 2012, Implications of dam obstruction for global freshwater fish diversity: BioScience, v. 62, no. 6, p. 539-548.

Lowe, W.H., and Allendorf, F.W., 2010, What can genetics tell us about population connectivity?: Molecular Ecology, v. 19, p. 3038-3051.

Luce, C.H., Abatzoglou, J.T., and Holden, Z.A., 2013, The missing mountain water: slower westerlies decrease orographic enhancement in the Pacific Northwest USA: Science, v. 342, no. 6164, p. 13601364.

Luce, C.H., and Holden, Z.A., 2009, Declining annual streamflow distributions in the Pacific Northwest United States, 1948-2006: Geophysical Research Letters, v. 36, L16401, 6 p. doi:10.1029/2009GL039407.

McLellan, J.G., 2001, 2000 WDFW Annual Report for the Project, resident fish stock status above Chief Joseph and Grand Coulee Dams: Spokane, Washington, Washington Department of Fisheries.

Mesa, M.G., Weiland, L.K., Christiansen, H.E., Sauter, S.T., and Beauchamp D.A., 2013, Development and evaluation of a bioenergetics model for bull trout: Transactions of the American Fisheries Society, v. 142, p. 41-49.

Moser, M.L., Ocker, P.A., Stuehrenberg, L.C., and Bjornn, T.C., 2002, Passage efficiency of adult Pacific lampreys at hydropower dams on the lower Columbia River, USA: Transactions of the American Fisheries Society, v. 131, p. 956-965. 
Muhlfeld, C.C., Jones, L., Kotter, D., Miller, W.J., Geise, D., Tohtz, J., and Marotz, B., 2012, Assessing the impacts of river regulation on native bull trout (Salvelinus confluentus) and westslope cutthroat trout (Oncorhynchus clarkii lewisi) habitats in the upper Flathead River, Montana, USA: River Research and Applications, v. 28, p. 940-959.

Myers, G.S., 1949, Usage of anadromous, catadromous, and allied terms for migratory fishes: Copeia, 1949, p. 89-97.

Nei, M., and Chakravarti, A., 1977, Drift variances for FST and GST statistics obtained from a finite number of isolated populations: Theoretical Population Biology, v. 11, p. 307-325.

Neraas, L.P., and Spruell, P., 2001, Fragmentation of riverine systems: the genetic effects of dams on bull trout (Salvelinus confluentus) in the Clark Fork River system: Molecular Ecology, v. 10, p. 11531164.

Nilsson, C., Reidy, C.A., Dynesius, M., and Revenga, C., 2005, Fragmentation and flow regulation of the world's large river systems: Science, v. 308, no. 5720, p. 405-408.

Piry S., Alapetite, A., Cornuet, J-M., Paetkau, D., Baudouin, L., and Estoup, A., 2004, GENECLASS2 - A software for genetic assignment and first-generation migrant detection: Journal of Heredity, v. 95, p. 536-539.

Prince, A., 2010, Subadult bull trout distribution and habitat utilization in the Salmo River and Seven Mile Reservoir (final report): Canadian Columbia River Inter-tribal Fisheries Commission and Westslope Fisheries Ltd., Seven Mile Project Water Use Plan, Study Period: October 2007 to May 2010.

Rahel, F.J., 2004, Unauthorized fish introductions-Fisheries management of the people, for the people, or by the people?, in Nickum, M.J., and others, eds., Propagated fishes in resource management, Symposium 44: Bethesda, Maryland, American Fisheries Society, p. 431-444.

Rieman, B.E., and Allendorf, F.W., 2001, Effective population size and genetic conservation criteria for bull trout: North American Journal of Fisheries Management, v. 21, p. 756-764

Sanderson, B.L., Barnas, K.A., and Rub, A.M.W., 2009, Nonindigenous species of the Pacific Northwest-An overlooked risk to endangered salmon?: BioScience, v. 59, p. 245-256.

Seaber, P.R., Kapinos, F.G., and Knapp, G.L., 1987, Hydrologic unit maps: U.S. Geological Survey Water Supply Paper 2294.

Selong, J.H., McMahon, T.E., Zale, A.V., and Barrows, F.T., 2001, Effect of temperature on growth and survival of bull trout, with application of an improved method for determining thermal tolerance in fishes: Transactions of the American Fisheries Society, v. 130, p. 1026-1037.

Stewart, I.T., Cayan, D.R., and Dettinger, M.D., 2005, Changes toward earlier streamflow timing across western North America: Journal of Climate, v. 18, p. 1136-1155.

Taylor, E.B., Pollard, S., and Louie, D., 1999, Mitochondrial DNA variation in bull trout (Salvelinus confluentus) from northwestern North America-Implications for zoogeography and conservation: Molecular Ecology, v. 8, p. 1155-1170.

Taylor, E.B., Yau, M.M., and Mattock, A.B., 2014, Population structure in three species of codistributed salmonid fishes in the Peace River and tributaries near a major proposed hydroelectric development in northeastern British Columbia, Canada: River Research and Applications, v. 30, p. 1020-1033, DOI:10.1002/rra.2712.

U.S. Fish and Wildlife Service, 1999, Endangered and threatened wildlife and plants-Determination of threatened status for bull trout in the coterminous United States: Federal Register, v. 64, no. 210 (1999), p. 58909-58933.

U.S. Fish and Wildlife Service, 2005, Draft bull trout core area conservation status assessment: Portland, Oregon, United States Fish and Wildlife Service. 
U.S. Fish and Wildlife Service, 2008, Bull trout (Salvelinus confluentus) 5-year review-Summary and evaluation: Portland, Oregon, United States Fish and Wildlife Service, http://www.fws.gov/pacific/bulltrout/5yr\%20Review/Bull\%20Trout\%205YR\%20final\%20signed\%20042508.pdf.

U.S. Fish and Wildlife Service, 2012, Biological opinion for the Boundary and Sullivan Creek projects: Pend Oreille County, Washington, Pend Oreille River, Commission Docket Numbers P-2144-038 and 2225-013.

Varley, J.D., and Gresswell, R.E., 1988, Ecology, status, and management of the Yellowstone cutthroat trout, in Gresswell, R.E., ed., Status and management of interior stocks of cutthroat trout: Bethesda, Maryland, American Fisheries Society, Symposium 4, p. 13-24.

Wenger, S.J., Luce, C.H., Hamlet, A.F., Isaak, D.J., and Neville, H.M., 2010, Macroscale hydrologic modeling of ecologically relevant flow metrics: Water Resources Research, v. 46, W09513, doi:10.1029/2009WR008839.

Wenger, S.J., Isaak, D.J., Rieman, B.E., Dunham, J.B., Young, M.K., Fausch, K.D., Luce, C.H., Neville, H.M., Nagel, D.E., Chandler, G.L., and Horan, D.L., 2011, Role of climate and invasive species in structuring trout distributions in the Interior Columbia Basin: Canadian Journal of Fisheries and Aquatic Resources, v. 68, p. 988-1008. 


\section{Appendix A. Molecular Genetic Insights into Connectivity between Salmo River Bull Trout and Populations Upstream of Albeni Falls Dam (Priest River, Lake Pend Oreille, Clark Fork River)}

As part of the Genetics Panel's activities, we reviewed existing genetic data and information that was relevant to the question of the degree of connectivity between bull trout from the Salmo River and areas upstream of the Boundary Dam (from the end of the last ice age to post-dam construction). This included reviewing existing literature and some new genetic analyses of microsatellite loci data that were provided by Patrick DeHaan (U.S. Fish and Wildlife Service, written commun., 2013; see also Bettles and others, 2005; DeHaan and Ardren, 2007).

Inferences of Historical and Contemporary Genetic Connectivity

The baseline genetic microsatellite genotypes of Bettles and others (2005) and DeHaan and Ardren (2007) has been augmented by increasing geographic sample and genetic locus coverage. For the following analysis, we used data on 13 populations assayed at 18 microsatellite loci (Patrick DeHaan, U.S.Fish and Wildlife Service, unpub. data, 2013. The samples included a representative range of areas from the Salmo River (Clearwater Creek and South Salmo River), the Priest River watershed (Uleda Creek, Indian Creek, Upper Priest River, Middle Fork East River, and Gold Creek), the Lake Pend Oreille drainage (Granite Creek, Trestle Creek, and Johnson Creek), and the Clark Fork River system (Albert Creek, Copper Creek, and upper Rock Creek). Owing to long computation times for some analyses, we did not use all available populations in the database $(>40)$, but instead used population samples from the Salmo River system and a representative set of population samples from each of the Priest River, Lake Pend Oreille, and Clark Fork River systems.

The analysis consisted of an explicit test of the hypothesis that there has been no, or very limited, historical genetic connectivity between Salmo River bull trout and areas upstream of Boundary Dam using the coalescent approach implemented in the MIGRATE software (Beerli, 2012). The MIGRATE analysis is not meant to provide realistic estimates of actual genetic connectivity, but rather is intended simply to explore the idea of potential relative levels of connectivity amongst sample areas. Next, we used the Bayesian model-based clustering analysis of STRUCTURE (Falush and others, 2003) to assess the degree of subdivision of bull trout into different genetic groupings, as well as the extent to which bull trout from the different sample areas consist of mixtures of fish from these different genetic groups. The observation of fish that consist of such genetic mixtures would be consistent with the idea of genetic connectivity between fish from different areas (but which could be a result of historical or contemporary movement and breeding of bull trout in different areas, or both). Finally, we used genetic assignment and exclusion tests implemented in GENECLASS (Piry and others, 2004) to test for the presence of contemporary movement of bull trout amongst areas. These tests use the microsatellite genotypes of individual fish to assess the probability of individual fish that were sampled in one area being members of genetic populations in other areas (that is, they immigrated to the sample locality). Specifically, the exclusion tests uses the observed allele frequencies for each population, in turn, to construct a random distribution of multilocus genotypes (10,000 in the current case) to represent "the universe" of possible genotypes in each sampled population. The procedure then invites the question: "what is the probability of observing any sampled individual bull trout's observed multilocus genotype in this simulated population of 10,000 genotypes?" If that probability for any particular bull trout is less than 5 percent (or more stringently 1 percent), that fish is "excluded" from the population being investigated. This simulation is done for each test population (and individual bull trout, in turn). 


\section{Estimates of Historical Genetic Connectivity}

The MIGRATE analysis is based on a genealogical or "coalescent" approach (Allendorf and others, 2013, p. 129) to examine the relationships amongst DNA sequences or population samples based on allele frequencies backwards through time to a point where the samples were identical (that is, just before the point of divergence). The MIGRATE analysis based on microsatellite genotype frequencies, therefore, simulates the process of genetic drift and mutation backwards in time and derives estimates of critical parameters of populations that influence the pattern of divergence forward in time (effective population size, migration, and mutation - assuming no natural selection). If we assume that the mutation rate of the loci is equal among populations, it can effectively be ignored in the analysis (this is a reasonable assumption, there is no reason to suspect that different bull trout populations would have different mutation rates at microsatellite loci). The MIGRATE analysis produces, using maximumlikelihood (ML) or Bayesian procedures, estimates of $\theta$ (theta, $=4 N_{e} \mu$ ) and $M$ (the ratio of migration rate to mutation rate, $m / \mu)$ along with 95 -percent confidence limits for posterior distributions $\left(N_{e}\right.$ is the effective population size and $\mu$ is the mutation rate). The product $\theta M$ is equal to the effective number of migrants per generation (Beerli, 2012). Such analyses are subject to a number of often very simplifying assumptions (for example, migration has been constant through time) that are unlikely to be met or fully met in natural populations. Nevertheless, some insights can be made at least from relative comparisons.

In the MIGRATE analysis, the 13 population samples were grouped into four areas to expedite analyses (which can be extremely intensive for multiple populations and loci); Salmo River Group ( $\mathrm{N}=$ two sites), Priest River Group ( $\mathrm{N}=$ five sites), Lake Pend Oreille Group ( $\mathrm{N}=$ three sites), and Clark Fork/Blackfoot Rivers Group ( $\mathrm{N}=$ three sites). The Bayesian and $\mathrm{ML}$ analyses produced approximate similar results under a variety of parameters (the general results did not change under these conditions) and all pointed to the same basic result-historical genetic connectivity, while detectable, is low $(<10$ individuals per year), especially in the direction of Salmo River to upstream areas ( $<$ one individual per year, table A1). The greatest degree of inferred movement was either from areas upstream of Boundary Dam to the Salmo River, between the Priest River and Lake Pend Oreille systems, or from these systems to the Clark Fork/Blackfoot Rivers (table A1).

Table A1. Estimates of long-term gene flow between localities within the Pend Oreille River system (grouped by major drainage), Washington.

[Estimates were based on coalescent analyses implemented in MIGRATE (Beerli, 2012) of bull trout from 13 localities and assayed at 18 microsatellite loci. The values represent inferred migration from the localities in the rows into the localities in the columns. For instance, an average $(\mathrm{N}=5)$ of 0.091 individuals per year were inferred to have moved from the Salmo River Group into the Lake Pend Oreille Group (or one individual every 10.9 years). Values are means from five separate analyses and are expressed as numbers of fish per year assuming a 5-year generation interval (Rieman and Allendorf, 2001). $\mathrm{NA}=$ not applicable]

\begin{tabular}{llllc}
\hline & \multicolumn{5}{c}{ Group } \\
\cline { 2 - 5 } & Salmo River & Priest River & Lake Pend Oreille & Clark Fork River \\
\hline Salmo River Group & $\mathrm{NA}$ & 0.114 & 0.091 & 0.449 \\
Priest River Group & 1.122 & $\mathrm{NA}$ & 1.166 & 0.926 \\
Lake Pend Oreille Group & 1.303 & 1.524 & $\mathrm{NA}$ & 1.330 \\
Clark Ford River Group & 0.299 & 0.233 & 0.308 & $\mathrm{NA}$ \\
\hline
\end{tabular}




\section{Genetic Groupings and Admixture}

The STRUCTURE analyses were run without locality priors, under a model of admixture, and allele frequencies correlated amongst localities and with 50,000 burn-in simulations followed by an additional 150,000 simulations, under hypothetical models of the number of genetic groupings that ranged from 1 to 20 . The most likely number of genetic groups across the data set was $K=2$ as determined by the $\Delta K$ criterion of Evanno and others (2005). The $K=2$ model tended to show that fish from Clearwater Creek (upper Salmo River), and fish from Lake Pend Oreille, the Clark Fork, and Blackfoot Rivers consisted almost exclusively of one genetic grouping, whereas bull trout from the Priest River watershed constituted fish from the other genetic group (fig. A1). Bull trout from the South Salmo River, Middle Fork East River, and Uleda Creek (Priest River), and upper Rock Creek (Clark Fork River) tended to have fish that were admixtures of both genetic groups. In the South Salmo River, admixed bull trout tended to be comprised largely of the genetic group found to predominate in the Lake Pend Oreille, Clark Fork, and Blackfoot Rivers. By contrast, fish from the Middle Fork East River were comprised largely of the genetic group that predominates in the Priest River system (fig. A1).

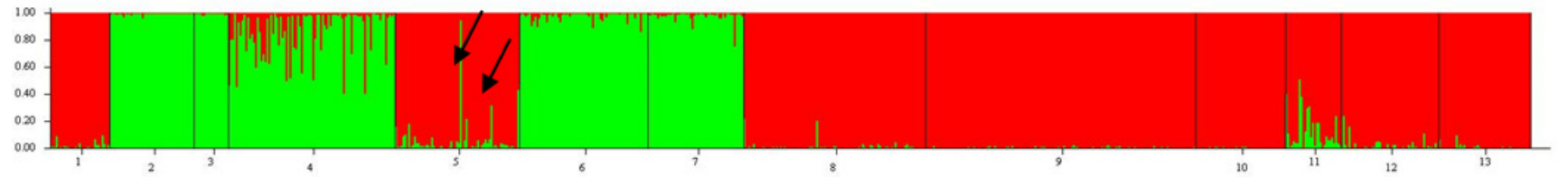

Figure A1. Results of STRUCTURE analysis (Falush and others, 2003) for bull trout (Salvelinus confluentus) sampled from the Pend Oreille River system and assayed at 18 microsatellite loci (Patrick DeHaan, U.S. Fish and Wildlife Service, unpub. data, 2013), Washington. Each fish is represented by a thin vertical line in which the height of each colored portion indicates the proportional genetic contribution $(Q)$ from each of the two genetic groups ("red" and "green"). Population codes: 1 = Clearwater Creek (Salmo River), 2 = Middle Fork East River (Priest River), 3 = Uleda Creek (Priest River), 4 = Indian Creek (Priest Lake), $5=$ South Salmo River, $6=$ Gold Creek (Priest Lake), 7 = Upper Priest River (Priest Lake), $8=$ Granite Creek (Lake Pend Oreille), $9=$ Trestle Creek (Lake Pend Oreille), 10 = Johnson Creek (Lake Pend Oreille), 11 = Upper Rock Creek, (Clark Fork River), 12 = Copper Creek (Clark Fork River), 13 = Albert Creek (Clark Fork River). Arrows indicate examples of admixed fish. 
To get a better idea of where the admixture in the South Salmo River bull trout might have originated, the analysis was re-run using $K=13$, one for each of the sample localities. Under this model, some South Salmo River bull trout still showed evidence of a small degree of admixture, largely from fish with genetic signatures characteristic of most fish from the Priest River system (specifically, Uleda Creek and the Middle Fork East River; fig. A2).

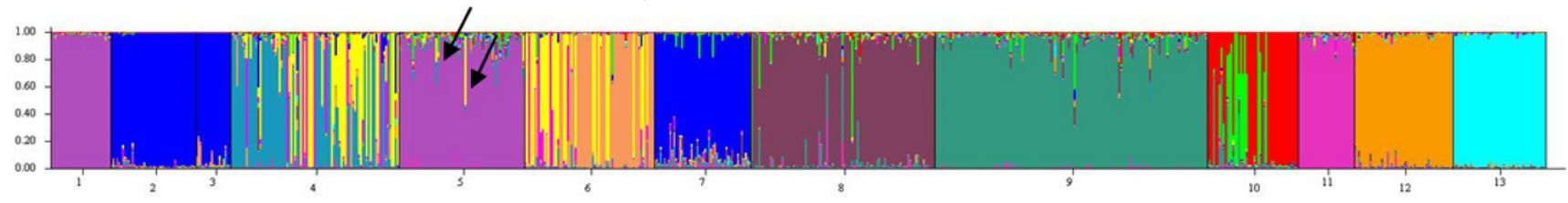

Figure A2. Results of STRUCTURE analysis (Falush and others, 2003) for bull trout (Salvelinus confluentus) sampled from the Pend Oreille River system and assayed at 18 microsatellite loci (Patrick DeHaan, U.S. Fish and Wildlife Service, unpub. data, 2013), Washington. Each fish is represented by a thin vertical line in which the height of each colored portion indicates the proportional genetic contribution $(Q)$ from each of the 13 sample localities (113). Population codes: 1 = Clearwater Creek (Salmo River), $2=$ Middle Fork East River (Priest River), $3=$ Uleda Creek (Priest River), $4=$ Indian Creek (Priest Lake), $5=$ South Salmo River, $6=$ Gold Creek (Priest Lake), $7=$ Upper Priest River (Priest Lake), $8=$ Granite Creek (Lake Pend Oreille), $9=$ Trestle Creek (Lake Pend Oreille), 10 = Johnson Creek (Lake Pend Oreille), $11=$ Upper Rock Creek, (Clark Fork River), 12 = Copper Creek (Clark Fork River), 13 = Albert Creek (Clark Fork River). Arrows indicate examples of admixed fish.

In summary, these analyses are consistent with the idea that there has been some small level of genetic connectivity between fish in at least the South Salmo River and areas upstream of the present location of the Boundary Dam. The bull trout from Clearwater Creek (upper Salmo River) are much more genetically homogeneous and show much less evidence of historical connectivity with upstream areas in the Pend Oreille system.

The genetic assignment tests revealed that all bull trout sampled from Clearwater Creek and the South Salmo River were assigned to their sample stream with 99-100 percent confidence (table A2). By contrast, 10 of 88 fish from the Middle Fork East River were assigned to Uleda Creek and 15 of 65 Uleda Creek fish were assigned to the Middle Fork East River. In addition, 3 of 95 fish from Granite Creek (Lake Pend Oreille) were assigned to other streams: 1 to the South Salmo River, 1 to Johnson Creek (Lake Pend Oreille), and 1 to Trestle Creek (Lake Pend Oreille). Finally, 1 of 48 fish from Johnson Creek was assigned to Trestle Creek. More stringent exclusion tests, however, showed that 3 fish in Clearwater Creek and 2 fish in the South Salmo River could be excluded as genetic members of those populations $(\mathrm{P}<0.05$, table $\mathrm{A} 2)$. None of these fish could, however, be confidently assigned to any of the other sample localities, so although they may represent immigrants into Clearwater Creek and the South Salmo River their provenance cannot be determined from the available data (that is, there is no evidence that they might represent fish, or their recent descendants, that originate from entrainment through Boundary Dam). None of the several fish that were excluded at $\mathrm{P}<0.05$ from tributaries upstream of Boundary Dam could be assigned to either of the Salmo River populations (table A2). Presumably, fish that are excluded from a population, but not assigned to another, represent immigrants from systems that have not yet been assayed genetically or that we did not include in our analysis (for example, mainstem Salmo River or unsampled tributaries of the Priest River and Lake Pend Oreille systems (for example, 13 of 41 areas assayed were used in the present analyses). This analysis suggests that the two tributaries of the Salmo River are current demographically isolated from each other and, as expected, from areas upstream of Boundary Dam (Bettles and others, 2005; DeHaan and Ardren, 2007). 
Table A2. Results of assignment tests for bull trout assayed at 18 microsatellite loci.

[Shown are the numbers of fish self-assigned to the locality where they were sampled ("Locality"), the numbers of fish from each sample locality assigned to other localities, the numbers of fish excluded (at $\mathrm{P}<0.05$ ) from the locality in which they were sampled, and the locality to which excluded fish were assigned (single fish unless otherwise indicated in parentheses). $\mathrm{UNK}=$ excluded fish could not be assigned to any of the 13 sample localities. NA = not applicable]

\begin{tabular}{lcccl}
\hline \multicolumn{1}{c}{ Locality } & $\begin{array}{c}\text { Number of fish } \\
\text { self-assigned }\end{array}$ & $\begin{array}{c}\text { Number of } \\
\text { fish assigned } \\
\text { to other } \\
\text { localities }\end{array}$ & $\begin{array}{c}\text { Number of fish } \\
\text { excluded from } \\
\text { home locality }\end{array}$ & $\begin{array}{l}\text { Locality where } \\
\text { excluded fish } \\
\text { were assigned }\end{array}$ \\
\hline Clearwater Creek & 31 & & & \\
South Salmo River & 65 & 0 & 3 & UNK \\
Middle Fork East River & 78 & 0 & 2 & UNK \\
Uleda Creek & 50 & 10 & 2 & Uleda Creek, UNK \\
Indian Creek & 18 & 15 & 1 & Middle Fork East \\
Gold Creek & 40 & 0 & 3 & River \\
Upper Priest River & 50 & 4 & 5 & UNK \\
Granite Creek & 92 & 0 & 5 & Upper Priest River \\
Trestle Creek & 140 & 3 & 5 & UNK \\
Johnson Creek & 47 & 0 & 12 & Trestle Creek, UNK \\
U. Rock Creek & 30 & 1 & 6 & UNK \\
Copper Creek & 51 & 0 & 4 & Trestle Creek, UNK \\
Albert Creek & 46 & 0 & 1 & (5) \\
\hline
\end{tabular}

\section{Relationship between Demographic Connectivity and Indirect Measures of Genetic Connectivity}

Notwithstanding the analyses previously summarized that suggest some degree of historical genetic connectivity between bull trout from the Salmo River and areas upstream of Boundary Dam, genetic connectivity and demographic connectivity (that is, dispersal and ecological integration of fish between areas that is of relevance to the persistence of bull trout) are not necessarily closely related to one another. For instance and for the purpose of illustration, Hastings (1993) argued that populations that exchange fewer than 10 percent of their population sizes are effectively demographically asynchronous (implying some demographic independence) from one another. According to the narrow conditions described by Hastings (1993) (Lowe and Allendorf, 2010), a population of bull trout of 100 
mature adults, receiving 9 or fewer individuals from another population would behave in such a way that suggested that its demographic trajectory was not influenced by those 9 immigrants. By contrast, the degree of genetic divergence between populations is measured by $\mathrm{F}_{\mathrm{ST}}$, the degree to which the total variation is allele frequencies is determined by interpopulation differences. Well known population genetic theory relates $F_{S T}$ to one indirect measure of interlocality dispersal at equilibrium by,

$$
F_{S T}=1 /\left(4 N_{e} m+1\right)
$$

where

$N_{e} \quad$ is the effective population size of localities, and

$m \quad$ is the interlocality migration rate (and the product $N_{e} m$ represents the number of migrants)(Lowe and Allendorf, 2010).

This expression assumes that migration between localities is random. That is, migration is equally likely to occur between localities regardless of how far apart they are geographically. Using this approach can severely underestimate the actual amount of migrants if nearby localities tend to be more similar genetically.

If one assumes a 9 percent migration rate $(m=0.09$, same as example above $)$ and an $N_{e}=100$, $F_{S T}=1 /[(4(100)(0.09)+1]=0.027$ suggesting modest genetic distinction between populations. Many also would infer a significant degree of demographic independence from just such a level of genetic distinction (under $N_{e} m=9$ fish). If, however, the same $m$ was experienced in a population with an $N_{e}$ of $1,000, \mathrm{~F}_{\mathrm{ST}}$ would be much lower $(0.0027$, implying much less genetic distinction and more demographic interdependence) because even though the proportion of migrants was the same, 0.09 , the actual number of migrants $\left(N_{e} m=1000 \times 0.09=90\right)$ is much higher (Allendorf and Phelps, 1981). Consequently, the same proportion of migrants in the two scenarios results in different estimates of genetic connectivity (determined by differences in $N_{e}$ ). Conversely, one could observe the same measure of genetic connectivity as estimated by $F_{S T}$ under different demographic conditions of $N_{e}$ and $m$. The take away message is that without reasonable estimates of $N_{e}$ of potentially interacting populations, indirect genetic estimates (such as by $F_{S T}$ ) of demographic connectivity are problematic. Furthermore, even direct estimates of connectivity using genetic data (for example, by individual genetic assignment methods) are difficult to relate to demographic connectivity without an understanding of how such immigrants contribute, or if they even do, to vital rates of recipient populations (Lowe and Allendorf, 2010).

Overall, what this discussion suggests is that despite some evidence of historical genetic connectivity between bull trout from the Salmo River system and areas upstream of Boundary Dam, it is highly unlikely that such genetic connectivity was of significant demographic significance. In addition, without realistic estimates of key demographic parameters such as effective population size and the ecological contribution of immigrants to vital rates of recipient populations, it is impossible to estimate the potential demographic consequences of any genetic connectivity inferred from molecular genetic data (Lowe and Allendorf, 2010). 


\section{Genetic Divergence under Complete Isolation}

An estimate of genetic divergence from a common gene pool by genetic drift as measured by $\mathrm{F}_{\mathrm{ST}}$ under complete isolation can be obtained from the expression:

$$
F_{S T}=1-\left(1-1 / 2 N_{e}\right)^{t}
$$

where $N_{e}=$ effective population size and $\mathrm{t}=$ time in generations (Nei and Chakravarti, 1977). Assuming an $N_{e}$ of only 100 bull trout and eight generations (approximately 40 years) since the closure of Boundary Dam yields an expected $F_{S T}$ of only 0.039 between Clearwater Creek/South Salmo River bull trout and upstream areas, yet a value more than four times higher (0.17) was observed (averaged across localities). Although effective population sizes have undoubtedly not been constant through time (which may influence degree of divergence), the overall average was likely higher than 100 , which would make the expected $F_{S T}$ even smaller, suggesting the observed $F_{S T}$ has developed across historical times and not since dam closure.

Rieman and Allendorf (2001) estimated that the $N_{e}$ of a bull trout population is approximately 20 percent of the number of adults in a population. Therefore, an $N_{e}$ of 100 corresponds to a population with approximately 500 spawning adults. 


\section{Appendix B. Protocol for Delineating Patches of Suitable Habitat for the Rangewide Bull Trout Vulnerability Analysis}

Patches on a landscape represent discrete locations that provide conditions suitable to support a life stage or entire life cycle of a species (Dunham and others, 2002b). In the case of bull trout, patches represent interconnected networks of streams with temperatures cold enough on a year-round basis to support spawning and early rearing. Determination of suitable thermal conditions is based largely on physiological and growth responses to temperature determined through laboratory experiments (Selong and others, 2001; Mesa and others, 2013) and associations between bull trout and temperature observed in broad-scale field studies (Dunham and others, 2003). Although bull trout can move widely outside of patches to utilize other habitats within or outside of stream networks on a seasonal or annual basis, patches represent the fundamental unit of the landscape that drive persistence of local populations (Dunham and others, 2002b).

Patch delineation was based on medium resolution National Hydrography Dataset (NHD; http://nhd.usgs.gov/) streams with modeled temperatures available at $1 \mathrm{~km}$ intervals, as provided by the NorWeST project (http://www.fs.fed.us/rm/boise/AWAE/projects/NorWeST.html). Using these data, we ran an ArcGIS ModelBuilder model (Environmental Systems Research Institute, Redlands, California) that automatically delineates patches in streams based on contiguous reaches of cold water. This process takes several steps, outlined in order here.

First, streams are filtered to remove reaches with an estimated mean summer streamflow of less than or equal to $0.034 \mathrm{~m}^{3} / \mathrm{s}$ (estimated using data from Wenger and others, 2010), which corresponds approximately to streams with widths unlikely to be used by bull trout $(<2 \mathrm{~m})$, based on Dunham and Rieman (1999). This purpose of this step is to remove patches with only small streams that are unlikely to support bull trout. Without this step literally hundreds of tiny patches can be generated within a given subbasin (eight-digit hydrologic unit code; Seaber and others, 1987).

After the streamflow filter was applied, remaining stream reaches were coded on the basis of their August mean temperature, predicted by the NorWeST effort. Stream reaches with predicted temperatures of $13^{\circ} \mathrm{C}$ or less were considered suitable, and coded as such. This temperature is near that for which maximum growth of bull trout fed on unlimited rations in laboratory conditions is observed, and far below temperatures at which bull trout begin to show signs of stress (Selong and others, 2001). In some cases, contiguous stream reaches that exceeded $13{ }^{\circ} \mathrm{C}$ were bounded on upstream and downstream ends by reaches with predicted temperatures of $13{ }^{\circ} \mathrm{C}$ or less. Accordingly, we needed a set of rules for determining whether to subsume these reaches into a patch or not based on: (1) the magnitude to which temperatures in such reaches exceeded $13{ }^{\circ} \mathrm{C}$, and (2) the distance over which such exceedances were observed. If the temperatures in a given reach bracketed by suitably cold reaches did not exceed $14.75^{\circ} \mathrm{C}$, and the length of the reach was less than $4 \mathrm{~km}$, we included this reach as part of the larger network within which it was embedded. If this distance was more than $4 \mathrm{~km}$, the cold-water network was split by the warm patch. We coded stream reaches with predicted August mean temperatures greater than $14.75^{\circ} \mathrm{C}$ to be unconditionally unsuitable (regardless of distance). This upper threshold translates into an approximate 5 percent decrease in growth relative to the fastest rate of growth observed by Selong and others (2001). 
Lakes and dams are special cases, and can override the temperature coding. If a reach or set of reaches that make up a lake intersects a suitable cold-water reach, those lake-coded reaches are recoded as suitable, regardless of the temperature of the lake. Wherever a dam lies within a stream reach, that reach is automatically coded as unsuitable, dividing potentially suitable patches into two or more. We identified dams from the Army Corps of Engineers National Inventory of Dams

( $h$ ttp://geo.usace.army.mil/pgis/f? $p=397: 1: 0$ ), which provides complete coverage for the range of bull trout, but does not cover the entire range of natural and human caused barriers that exist on the landscape.

Finally, after all stream reaches were coded, we implemented a GIS buffering process to identify contiguous stream reaches and to number each individual "patch" consecutively to provide unique identifiers. 
Publishing support provided by the U.S. Geological Survey Publishing Network, Tacoma Publishing Service Center

For more information concerning the research in this report, contact the Director, Forest and Rangeland Ecosystem Science Center U.S. Geological Survey

777 NW 9th St., Suite 400

Corvallis, Oregon 97330

http://fresc.usgs.gov/ 


\section{हू}

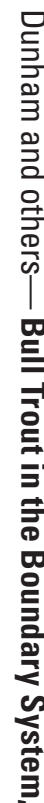

¿̄

$\stackrel{\Phi}{7}$

ㅇํㄹ

오․

꿍

극

ब.

올

$\sum_{0}$

을.

흥

?

$\stackrel{0}{3}$

旁

ग

응

옹

$\frac{1}{N}$ 